\title{
弾塑性域における軸方向力をうける \\ H型断面部材の研究
}

正会員牧野稔*

\section{\$1. 序}

弾塑性域にわける昖張された撓角法では，部材の形状 が係数に影響するようになる。矩形断面部材に対する取 扱いの一例は，先㳊筆者”が考察したが，本論文では， この取报いを軸方向圧縮力を受けるH型あるいは箱型な ぞ実用断面形のものに抁張し，材形や材質の変化した之 きの変形に及ぼす影響を考光，ラーメンの柱の設計につ いて簡単な考察を加えた。解析に当り仮定した事項はお よそ次の通りである。

i）部材は一様で，断面は二軸対称の $\mathrm{H}$ 型あるいは箱 型とし，フランジの厚さは部材の丈に比較して小さ く，曲げは強度の大きい方の軸について考えるもの とする。

ii）内部せん断力の影響は無視されるものとする。

iii）部材の忘力・霆曲線は第 1 図に示すような完全弾塑 性とする。

iv）断面の平面保持の仮定は 満足されるものとしなお 曲率は小さいと考光る。

v）局部座屈は生じないとす る。

vi）部材に打汀る外力の釣合

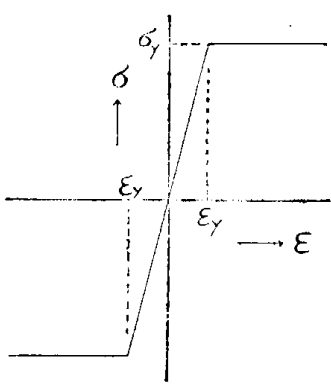

第1図 材料の念力麥 曲線

は変形した形で考えるもの上する。

\section{\$2. 断面諸係数}

断面の形状寸法を第 2 図のようにとり,フランジの厚 さを丈に比較して無視し，フランジの中心伦置に集中し た面積があると考えるととにする。いまフランジの合計 面積を $A_{f}$ ウェブの合計面積を $A_{w}$ として $\rho=\frac{A_{f}}{A_{w}}$ と

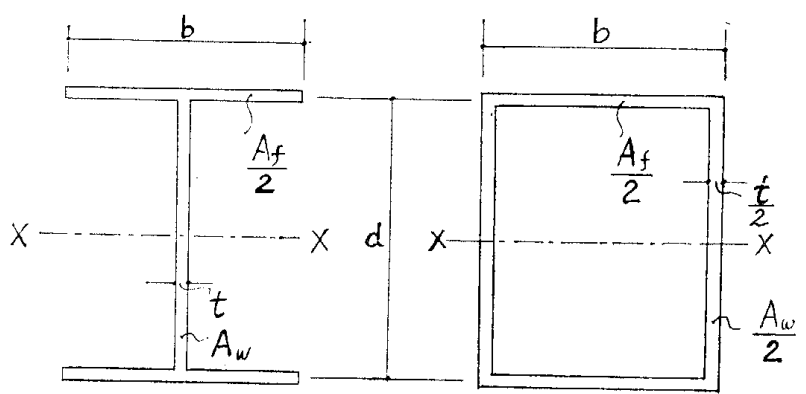

第 2 図断面の形状

* 建設省建築研究所研究員 工博

（昭和 39 年 1 月 30 日本稿受理，討論期限昭和 39 年 9 月末日）
置くと，

$\begin{array}{ll}\text { 全断面積 } & A=A_{w}+A_{f}=(1+\rho) t d \\ \text { 断面二次モーメント } & I=(1+3 \rho) \cdot \frac{t d^{3}}{12} \\ \text { 断面係数 } & Z=(1+3 \rho) \frac{t d^{2}}{6} \\ \text { 塑性断面係数 } & Z_{p}=(1+2 \rho) \frac{t d^{2}}{4} \\ \text { 断面二次半堡 } & i=\sqrt{\frac{1+3 \rho}{12(1+\rho)}} d\end{array}$

また $\sigma_{y}$ を降伏点応力度とすると，

降伏断面力 $P_{y}=A \sigma_{y}=(1+o) t d \sigma_{y}$

降伏モーメント $M_{y}=Z \sigma_{y}=(1+3 \circ) \frac{t d^{2}}{6} \sigma_{y}$

全塑性モーメント $\quad M_{p}=Z_{p} \sigma_{y}=(1+2 \rho) \frac{t d^{2}}{4} \sigma_{y}$

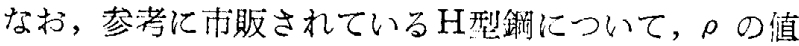
を求少ると，幅と丈の活住等しい広幅系列のものは $\rho=$ $2 \sim 3$ 前後, 幅が丈の $1 / 2 \sim 1 / 3$ の幅の狭い系列 の方の は， $\rho=1.5 \sim 2$ 位である。また箱型の沙方形の対称断面 では $\rho=1$ とす机ばよい。

\section{§3. 記号}

前節に示した外，しばしば朋いら机る記男をまるめて 示すと，次のとうりである。

$d:$ 部材の丈でフランジ重心間距離とする。

$h:=\frac{M_{A B}}{M_{y}} \mathrm{~A}$ 端における材端モーメントと降伏モ ーメントとの比，時計迴りの方向を正とする。 $k:=\frac{M_{B A}}{M_{y}} \mathrm{~B}$ 端にお汀る材端モーメントと降伏モ ーメントとの比，時竍趣りの方向を正とする。

$l:$ 部材の長さ

$t:$ ウブの厚さ

$x, y:$ 直角座標

$E:$ ヤング率

$M:$ 曲げモーメント

$M_{y}{ }^{\prime}$ : 軸方向力の存在するときの降伏モーメント $M_{p^{\prime}}$ : 軸方向力の存在する之きの全塑性モーメント

$P:$ 存在軸方向圧縮力

$P_{e}:=\frac{\pi^{2} E I}{l^{2}}$ 部材の両端をピンとしたときのいわゆ

る Euler の座屈荷重

$R$ : 部材角

$\eta:=\frac{P}{P_{y}}$ 存在軸方向圧縮力と降伏断面力之の比 


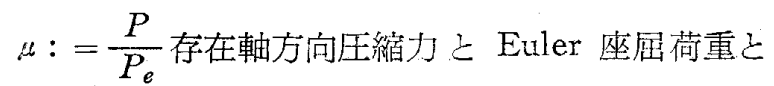
の比

$\theta_{A}, \theta_{B}: \mathrm{A}$ 端およよひ $\mathrm{B}$ 端の材端角

\$4. 変形計算の基礎式（部材断面におけるモーメン 卜上曲率の関係)

仮定より曲率を $\phi$, 曲げ風性を $E I$, 曲げモーメントを $M$ とすれば，弾性範囲では明らかに，

$$
\phi=\frac{M}{E I}
$$

塑性範围では第 3 図を参照すれば，

$$
\phi=\frac{\varepsilon_{\mathrm{ext}}}{C}=\frac{\varepsilon_{y}}{z}=\frac{\sigma_{y}}{E z}
$$

(2) 式の場合には，曲げモーメント $M$ と $z$ との関 係を求㸚ばならない。いま軸方向圧縮力を $P$ とし， 断面の中心からの偏心を $e$ とすれば $M=P \cdot e$ で表わさ れる。

断面の王縮縁のみ降伏領域にある場合を CaseＩ圧縮 縁，引張縁共降伏領域にある場合を CaseII とすると， 力の釣合は CaseI の場合，第3図より，

$$
\left.\begin{array}{l}
P=(c-z) t \sigma_{y}+\frac{1}{2} z t \sigma_{y}-\frac{1}{2}(d-c) t \frac{d-c}{z} \sigma_{y}+\frac{\rho}{2} t d \sigma_{y}-\frac{\rho}{2} t d \frac{d-c}{z} \sigma_{y} \\
P\left(c-\frac{d}{2}+e\right)=\frac{1}{2}(c-z)(c+z) t \sigma_{y}+\frac{1}{3} z^{2} t \sigma_{y}+\frac{1}{3} \frac{(d-c)^{3}}{z} t \sigma_{y}+\frac{\rho}{2} t d c \sigma_{y}+\frac{\rho}{2} \frac{(d-c)^{2}}{z} t d \sigma_{y}
\end{array}\right\}
$$

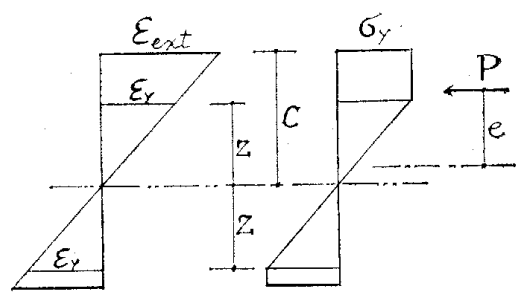

歪分布庶力分布

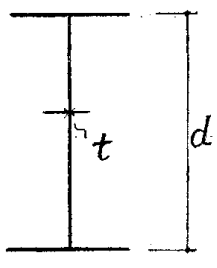

部材断面
第 3 図 塑性状態 (case I)

第 4 図 塑性状態 (case II)

Case III の場合，第 4 図上b

$$
\left.\begin{array}{l}
P=(c-z) t \sigma_{y}-(d-c-z) t \sigma_{y} \\
P\left(c-\frac{d}{2}+e\right)=\frac{1}{2}(c-z)(c+z) t \sigma_{y}+\frac{2}{3} z^{2} t \sigma_{y}+\frac{1}{2}(d-c-z)(d-c+z) t \sigma_{y}+\frac{\rho}{2} t d c \sigma_{y}+\frac{\rho}{2}(d-c) t d \sigma_{y}
\end{array}\right\}
$$

ととで $\frac{z}{d}=\alpha, \frac{c}{d}=\beta$ とすると

Case I の場合

$$
\begin{aligned}
& P=P_{y} \frac{1}{1+\rho} \cdot \frac{1}{2 \alpha}\left[3 \beta \alpha--\alpha^{2}-(1-\beta)^{2}+\rho(\alpha-1+\beta)\right] \\
& M=M_{y} \frac{1}{1+3 \rho}\left[3 \beta-3 \beta^{2}+\left(3 \beta-\frac{3}{2}\right) \alpha-\alpha^{2}+\frac{1}{\alpha}\left(\frac{1}{2}-\frac{3}{2} \beta^{2}+\beta^{3}\right)+\frac{3}{2} \rho\left\{1+\frac{1}{\alpha}(1-\beta)\right\}\right]
\end{aligned}
$$

Case II の場合

$$
P=P_{y} \frac{1}{1+\rho}(2 \beta-1), M=M_{y} \frac{1}{1+3 \rho}\left(6 \beta-6 \beta^{2}+3 \rho-2 \alpha\right)
$$

また（2）式は，次の式となる。

$$
\phi=\frac{M_{y}}{E I} \cdot \frac{1}{2 \alpha}
$$

存在䧿方向压縮力が一定で降代断面力との比を $\eta=\frac{P}{P_{y}}$ として $\beta$ を消去すると，

(5) 式子b

$$
\begin{aligned}
& 2 \alpha=\frac{1}{8(1+\rho)^{3}(1-\eta)^{3}}\left[\left\{3(1+\rho)^{2}(1-\eta)-(1+3 \rho) \frac{M}{M_{y}}\right\}^{2}-9(1+\rho)^{2}(1-\eta)^{2}\right. \\
& +\sqrt{\left[\left\{3(1+\rho)^{2}(1-\eta)-(1+3 \rho) \frac{M}{M_{y}}\right\}^{2}-9(1+\rho)^{2}(1-\eta)^{2}\right]^{2}} * \\
& \left.+32(1+\rho)^{3}(1-\eta)^{3} \rho^{3}\left\{3(1+\rho)(1-\eta)-(1+3 \rho) \frac{M}{M_{y}}\right\}\right]
\end{aligned}
$$

(6) 式占

$$
2 \alpha=\sqrt{3-3(1+\rho)^{2} \eta^{2}+6 \rho-2(1+3 \rho) \frac{M}{M_{y}}}
$$

が求まり，(7) 式と組合わせると塑性域における曲率が定まる。 
第 1 表 モーメントの釣合う咪面の応力分布状態

\begin{tabular}{l|c|c}
\hline & $(1+\rho) \eta>1$ & $(1+\rho) \eta<1$ \\
\hline 弹 性 域 & $\left|\frac{M}{M_{y}}\right| \leqq(1-\eta)$ \\
\hline 塑性域 Case I & $(1-\eta)<\left|\frac{M}{M_{y}}\right| \leqq \frac{3(1+\rho)(1-\eta)}{1+3 \rho} \cdots \cdots(10)$ & $(1-\eta)<\left|\frac{M}{M_{y}}\right| \leqq \frac{1+3 \rho+(1+\rho) \eta-2(1+\rho)^{2} \eta^{2}}{1+3 \rho}$ \\
\hline 塑性域 Case II & 存 在 世 ず & $\frac{1+3 \rho+(1+\rho) \eta-2(1+\rho)^{2} \eta^{2}}{1+3 \rho}<\left|\frac{M}{M_{y}}\right| \leqq \frac{3+6 \rho-3(1+\rho)^{2} \eta^{2}}{2(1+3 \rho)} \cdots \cdots . .(11)$ \\
\hline
\end{tabular}

ここで，曲げモーメントと釣合う応力分布状態を求め ると，第 1 表のようになる。

表中 $(1+\rho) \eta<1$ という条件は, 全塑性モーメント $M_{p}^{\prime}$ のとき，中立軸がウェブにあるための条件である。 $(1+\rho) \eta>1$ のときは中立軸がフランジにある場合で,フ ランジの厚さを省略して，一点に集中して代表させたの で，乙の場合 Case II の釣合状態は存在しない。

なお（10）式と（11）式の右辺は軸方向力と, 全塑性

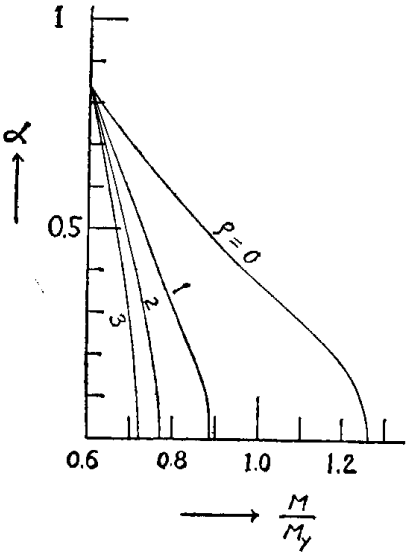

第 5 図 モーメントと $\alpha$ との 関係 $(\eta=0.40$ 場合 $)$ モーメントとのいわゆる Interaction Curve を示 すもので $\frac{M_{y}}{M_{p}}=\frac{2(1+3 \rho)}{3(1+2 \rho)}$ 在代入すればよく知ら れた式でフランジの暻さ を集約した場合となる。

さらに，ここで塑性域 におけるモーメントと曲 率に反比例する $\alpha$ との関

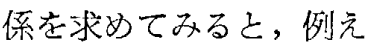
ば $\eta=0.4$ の場合 $\rho=0$, $1,2,3$ について第 5 図の ようになる。

\section{§5. H 型あるいは箱型材の弾塑性域における暁角法 係数}

軸方向圧縮打と曲げモーメントを受けて変形し，釣合 の状態にある一様な中間荷重のない場合の部材を図示す ると，第 6 図のようになる。

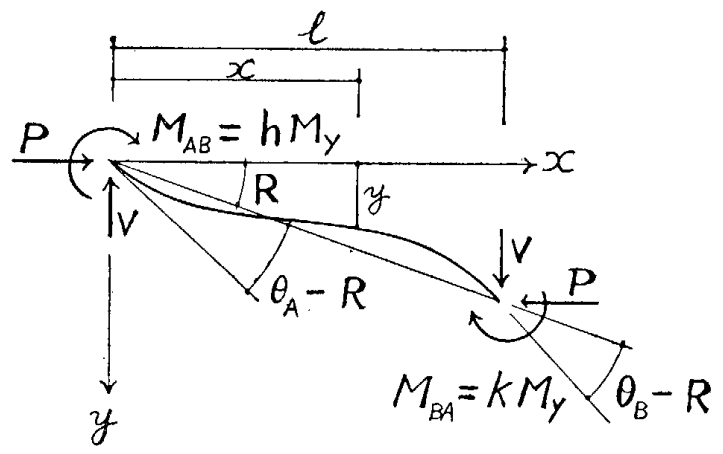

第 6 図 部材の変形後の釣合

ここに $h=\frac{M_{A B}}{M_{y}}, k=\frac{M_{B A}}{M_{y}}$ とすると, $A$ よ $x$ の距 離の位置における外力のモーメントは

$$
M=M_{y}\left[h-(h+k) \frac{x}{l}\right]+P(y-R x)
$$

また曲率は

$$
\phi=-\frac{d^{2} y}{d x^{2}}
$$

と表わされるので（8）あるいは（9）式と組合せると， 第 6 図のようなモーメント分布の部材の弾塑性域にわた る微分方程式が定まる。

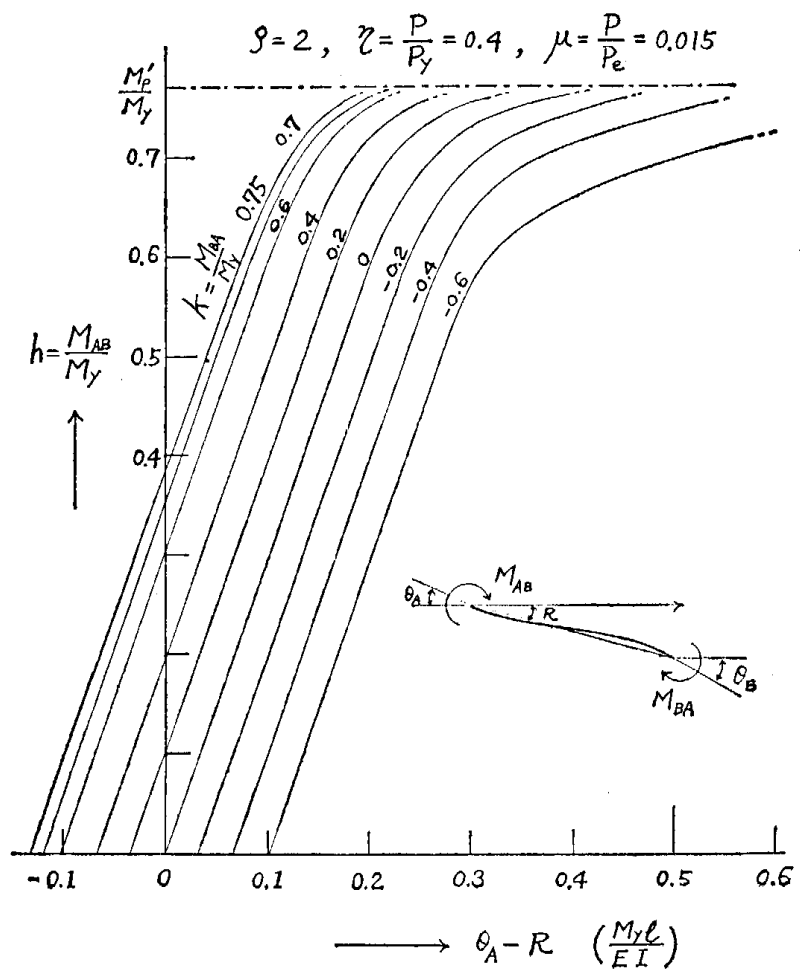

第 7 図 弾望性域に招ける暁角法係数（その1）

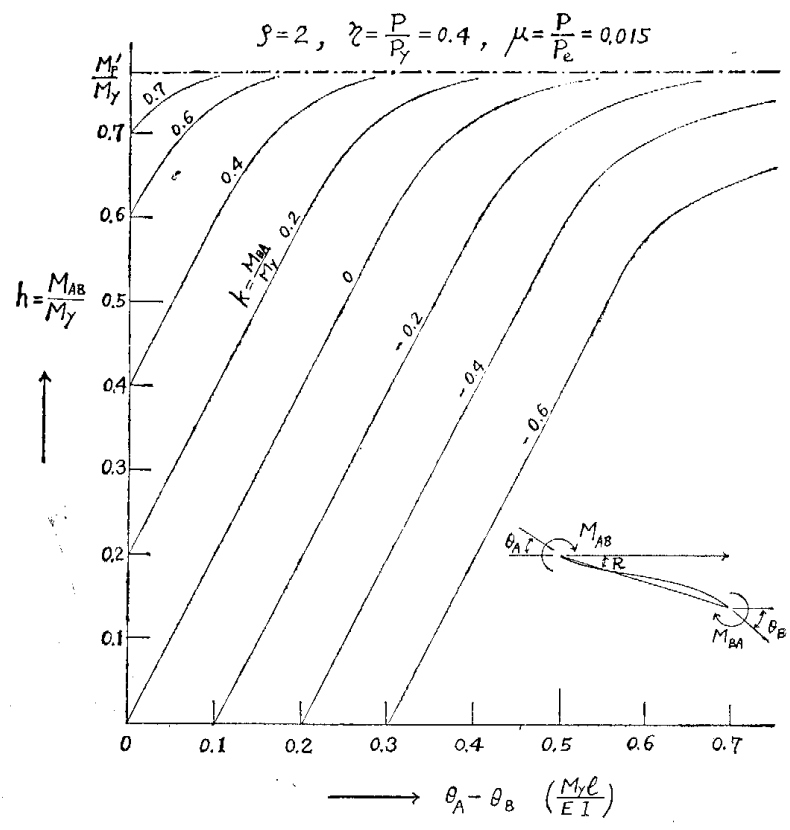

第 8 図 弾塑性域に打暁角法係数（その2） 
Euler の坐屈荷重 $P_{e}=\frac{\pi^{2} E I}{l^{2}}$ 之存在軸方向圧縮力 $P$ との比を $\mu=\frac{P}{P_{e}}$ とすれば，前に筆者が述べたように， これらの微分方程式が数值的にとけるようになる。例壳 ば, $\rho=2, \mu=0.015, \eta=0.4$ の場合，全区間を 64 等分 し, Lunge-Kutta の数值積分公式で解いた結果の一部 を図示すると，第 7 図および第 8 図のようになる。

なお， $\eta=0.4$ 之一定して， $\mu$ を変化させた場合の暁 角係数の変化の一例を示すと，第2 表の上うになる。ク

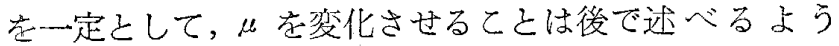
に，部材の細長此を变えるととに相当するが，てれによ ると逆刘称モーメント分布のときは変化が少なく, 三角 形分布となるとかなり影響が著しくなるととがわかる。 したがって，第 7 図と第 8 図をルのあまり異なったと こらに準用するととのできないととがわかる。

第 2 表 $\eta=0.4, \rho=2$ のときの楛角係数

$$
\theta_{A}-R \quad\left(\frac{M_{y} l}{E I}\right)
$$

\begin{tabular}{|c|c|c|c|c|c|}
\hline & モーメント分侮 & $\mu=0$ & $\mu=0.015$ & $u=0.05$ & $\mu=0.1$ \\
\hline \multirow{4}{*}{$\begin{array}{l}\theta_{h}^{k} \\
\theta_{h}^{A}\end{array}$} & $h=k=0.6$ & 0.1 & 0.10025 & 0.10083 & 0.10168 \\
\hline & $h=k=0.7$ & 0.128 & 0.128 & 0.129 & 0.131 \\
\hline & $h=k=0.75$ & 0.164 & 0.165 & 0.167 & 0.171 \\
\hline & $h=k=0.76$ & 0.179 & 0.180 & 0.183 & 0.187 \\
\hline \multirow{5}{*}{ 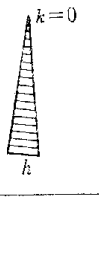 } & $h=0.6 \quad k=0$ & 0.2 & 0.2020 & 0.2069 & 0.2145 \\
\hline & $h=0.7 \quad k=0$ & 0.256 & 0.259 & 0.268 & 0.283 \\
\hline & $h=0.75 k=0$ & 0.328 & 0.335 & 0.353 & 0.391 \\
\hline & $h=0.76 \quad k=0$ & 0.359 & 0.367 & 0.391 & 0.448 \\
\hline & \multicolumn{2}{|c|}{$\theta_{A}-\theta_{B}$} & $\left(\frac{M_{y} l}{E I}\right.$ & & \\
\hline \multirow{4}{*}{$\mathrm{E}_{h}^{h=0}$} & $h=0,6 \quad k=0$ & 0.3 & 0.3038 & 0.3130 & 0.3274 \\
\hline & $h=0.7 \quad k=0$ & 0.373 & 0.379 & 0.393 & 0.417 \\
\hline & $h=0.75 \quad k=0$ & 0.457 & 0.466 & 0.492 & 0.542 \\
\hline & $h=0.76 \quad k=0$ & 0.490 & 0.503 & 0.533 & 0.605 \\
\hline
\end{tabular}

\section{\$6. 常数間の関係}

i) 細長比々存在軸方向圧縮力との関係

$$
P=\eta P_{y}=\mu P_{e}
$$

เり

$$
\eta=\frac{\pi^{2}}{\frac{\sigma_{y}}{E}\left(\frac{l}{i}\right)^{2}} \mu
$$

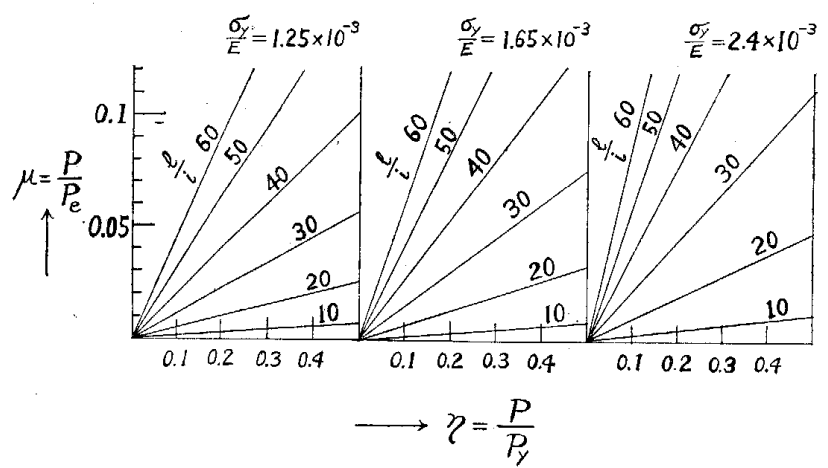

第 9 図 部材の細長比と存在軸方向圧縮力との関係
ことに $i=\sqrt{\frac{I}{A}} て ゙ \frac{l}{i}$ は部材の曲げの方向に抢ける細 第 3 表 材質の常数 $\sigma_{y} / E$ 長比である。

\begin{tabular}{l|l}
\multicolumn{2}{c}{ の值 } \\
\hline 軟 鋼 & $1.25 \times 10^{-3}$ \\
50 キ口鋼 & $1.65 \times 10^{-3}$ \\
60 キ口鋼 & $2.40 \times 10^{-3}$ \\
\hline
\end{tabular}

したがってクとルとの間 には材質と細長比で定まる関 係が成立する。いま，第 3 表 のように材質の常数を仮定す ると，(15）式は第 9 図に示すような関係となる。

ii）变形量の単位 $\left(\frac{M_{y} l}{E I}\right)$ について

変形量の単位 $\left(\frac{M_{y} l}{E I}\right)$ 飞断面諸係数を代入し整理す ると，形状に関係する。に無関係に次式となる。

$$
\frac{M_{y} l}{E I}=\frac{2 \sigma_{y}}{E} \cdot \frac{l}{d}
$$

これは部材の寸法と材質で定まるわけで，てれより， $\frac{M_{y} l}{E I}$ の単位と角度の関係を第 3 表の值について求少る と，第 10 図倸すようになる。なお，階高を想定すれ ば，層間変形量も求められるので参考に一緒に示した。

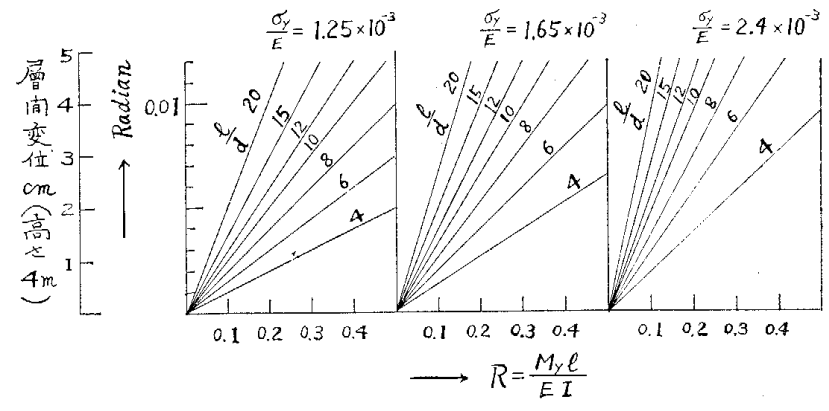

第 10 図 部材角の単位角の関係

\section{§7. 柱の丈と断面積を一定としたときの柱の変形性} 状

こてでは柱の丈 $d$ と瞇面皘 $A$ および降伏点虎力度 $\sigma_{y}$ を一定として，断面形状を変化させた場合の影響を調べ てみよう。

断面積一定の条件より $t$ を消去すると, 軸方向力の存 在しているときの降伏モーメントは

$$
M_{y^{\prime}}{ }^{\prime}=(1-\eta) \frac{1+3 \rho}{6(1+\rho)} A d \sigma_{y}
$$

また全塑性モーメントは $(1+\rho) \eta<1$ の場合

$$
M_{p}{ }^{\prime}=\frac{1+2 \rho-(1+\rho)^{2} \eta^{2}}{4(1+\rho)} A d \sigma_{y}
$$

$(1+\rho) \eta>1$ の場合

$$
M_{p^{\prime}}=\frac{(1-\eta)}{2} A d \sigma_{y}
$$

中立軸がフランジをある場合，曲げ強度が一定で阯面形 状に影響されないという当然の結果が得られる。

ことで $\rho=0$ のときの $M_{y}{ }^{\prime}$ を $M_{y_{0}}{ }^{\prime}$ としての值を 1 として, てれらの強度の此を求めてみると，第 4 表のよ うになる。全塑些モーメントに対しては $\eta=0.4$ のとき を考えた。 


\begin{tabular}{c|cccccc} 
第 4 表 & \multicolumn{3}{c}{$M_{y^{\prime}}{ }^{\prime}$ および } & $\eta=0.4$ & のときの $\frac{M_{p}{ }^{\prime}}{M_{y_{0}}{ }^{\prime}}$ の値 \\
\hline$\rho$ & 0 & 1 & 2 & 3 & 4 & $\infty$ \\
\hline$\frac{M_{y^{\prime}}}{M_{y 0^{\prime}}}$ & 1 & 2 & $7 / 3$ & 2.5 & 2.6 & 3 \\
\hline$\frac{M_{p^{\prime}} !}{M_{y 0^{\prime}}{ }^{\prime}}(\eta=0.4)$ & 2.1 & 2.95 & 3 & 3 & 3 & 3 \\
\hline
\end{tabular}

これらの関係を用い, 第 11 図 に示すような両端に材端角を生じ ないで部材角のみを生ずる材の変 形曲線を求めてみると， $\eta=0.4$, $\frac{l}{d} \fallingdotseq 5.0$ ○場合第 12 図に, $\eta=$ $0.4, \frac{l}{d} \fallingdotseq 12.8$ の場合第 13 図に 示すようになる。

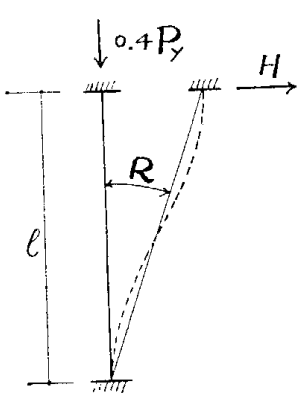

○が大きくなると曲げ耐力が增

第 11 図

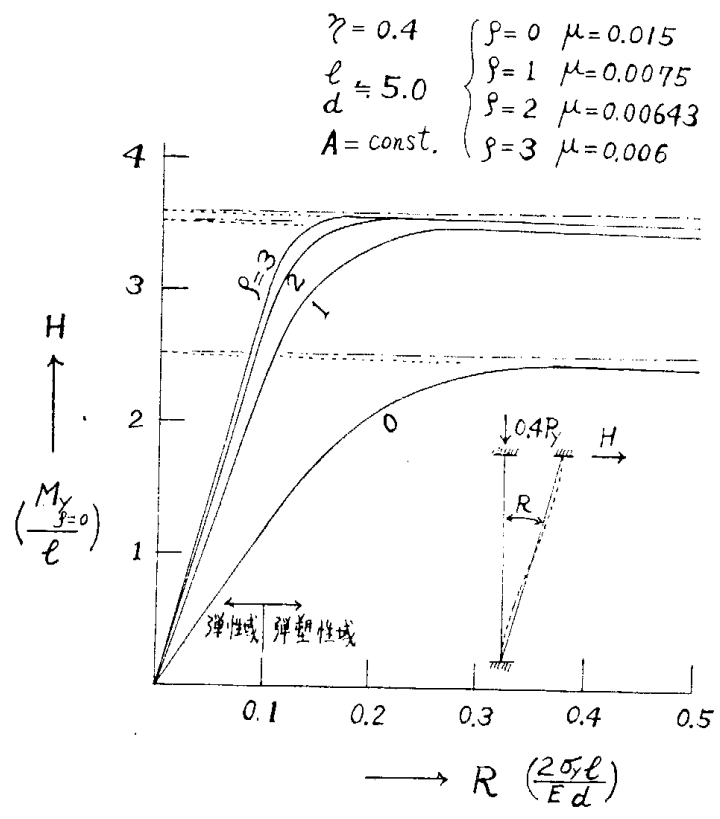

第 12 図

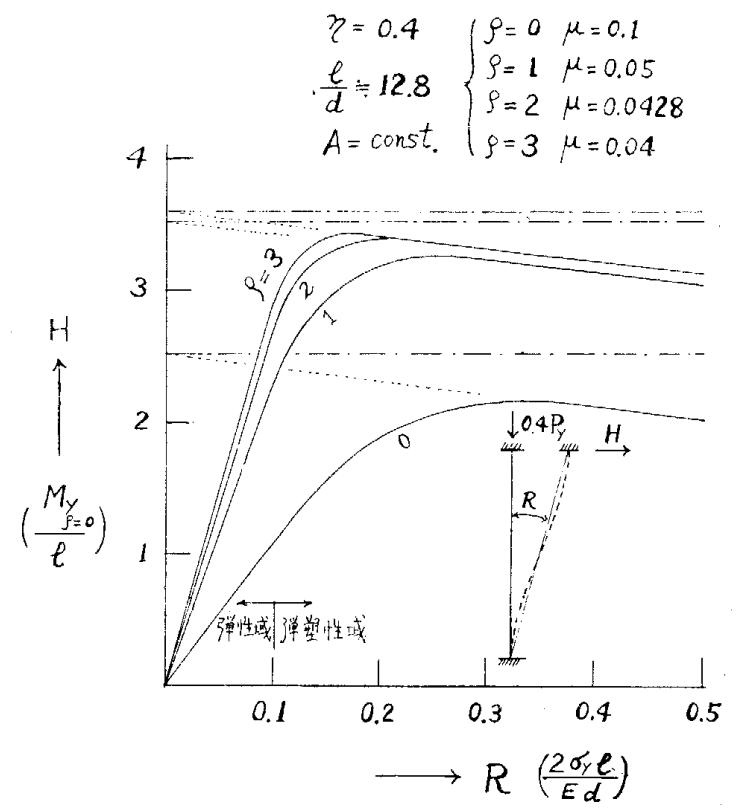

第 13 図
加するが，それは 1.5 までであって，それ以上では曲 げ耐力は増加せず，一方 $\rho$ が大きくなるほど， $\mu$ 注多 少小さくなっても最大值までの変形性能が小さくなる。 変形性能より見ると, $\eta=0.4$ の場合には, $\rho=1.5$ より やや小さい $\rho=1$ すなわち, 箱型断面のような形を選択 するのが適切なのではなからうか。

ここで $\frac{l}{d} \fallingdotseq 5.0$ と 12.8 の場合を求めたのは, 最大 耐力後の耐力低下を比較するためで $\mu=0.05$ ではかな り耐力低下がいちじるいことがわかる。

\section{§8. 鉄骨ラーメンの柱の設計について}

建物の安全性方ら見て, 最大酎力後急速汇耐力を失う ような変形性状を示吉部材代対しては，安全率を比較的 大きくとるのが一般であらう。ところが高首建物を質点 系切方少えて求められる地震応答において，そのバネ 飞 Negative bi-linear の澍重変形特性老考えると, 塑 性域で安定な応答が得られないととが知られている。一 方その設阡に当っては, ある程度の塑性変形を許すとと が落虑されている。したがって, 荷重変形特性には急激 な耐力低下をさけるべきものであるう。

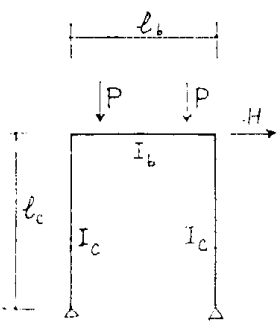

(a)

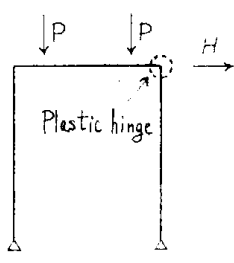

(b)

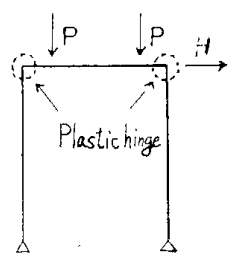

(c)

\section{第 14 図}

水平力を受けるラーメンの荷重変形胒線に耐力低下が 生ずるのは，骨組が Collapse mechanism に達した後 ばかりでなく，軸力の大きさと邚比の関係によってはそ れ以前に生ずることがある。一例として，第 14 図 (a) に示すラーメンが，(b) の状態を経て (c) で Collapse mechanism になって不安定となるのは，もし $\frac{I_{b} l_{c}}{I_{c} l_{b}}=$ 0.198 とすると $\mu=0.05$ 以下のときであって, $\mu=0.05$ 以上のときは，(b) の状態が不安定となるととを示すと とができる。

このような取扱より，塑性域にわたる柱の設計式とし て, AISC の仕様書 ${ }^{2}$ の Plastic Design の項では, 節 点の拘束されていない柱の条件式を本諭文の記号を用い ると，

$$
2 \eta+\frac{1}{70} \cdot \frac{l}{i} \leqq 1
$$

で与えている。

第9図に示す（15）式を書き直し，(17）式を記入す ると, 第 15 図となり, 柱の荷重変形特性との関係が明 らかとなる。(17) 式ではラーメンの柱の通常の限界々 して, 梁の弱い場合も予想し， $\mu=0.05$ が限度となった 


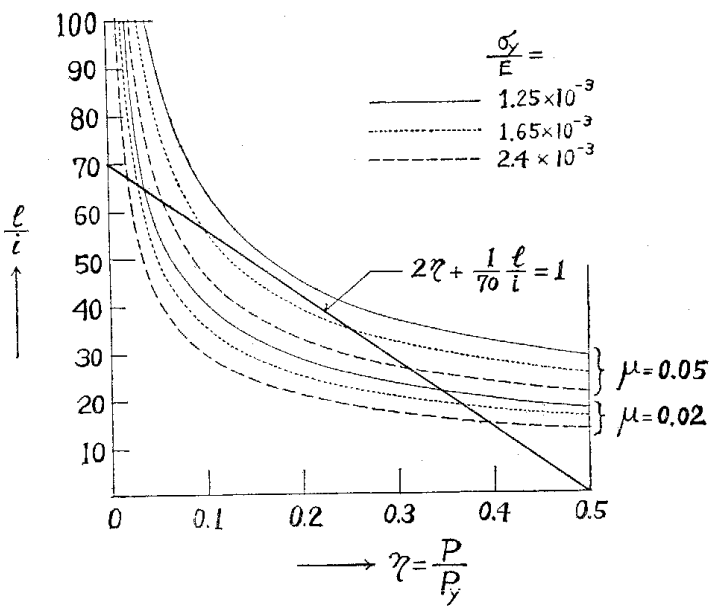

第 15 図 部材の細長比と存在軸方向圧縮 との関係（その2）

と考光られる。

高層ラーメンの設計で強震時に塑性域まで変形を認め た場合，load factor の大きさにもよることではあるが， 一層ラーメンの場合より安全を見込んで例えば $\mu=0.02$ 程度で設計を進めるべきではなからうか。この程度で岗 れば最大耐力後の耐力低下は前に示したとうりで，急激 な耐力低下をさけることができる。

$\mu$ の值を定めると，第 9 図より柱の大きさ，すなわち 細長比 $l / i$ 之断面降伏比 $P / P_{y}=\eta$ の選択の範图が材質 によって定めうれる。乙れより曲げ耐力と変形性状を考 虑し， $(1+\rho) \eta<1$ なぞより 断面形状を決定することが できる。実際には，さらに局部來屈の影響などを考慮し なければならないととはいうまでもないととである。

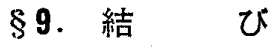

ここで考察したととろをまる，所見を加えてみる 之,

i）フランジの厚さを集約して式を簡略化した誤差は 形状係数 $Z_{p} / Z$ や Interaction Curve の值で数\% 以内である之推定され，乙の簡略化は仮定条件より 見ると定性的な解析には罗当な处理方法であるう。

ii）数值計算では，本論文で用いた理論式よりは理論 式に基ずく近似式，例气ば第 5 図に示すような曲げ モーメントと曲率の関係図より,チェどシェフの多 項近似式を求めて計算する方が計算化便利である う。さらにての方法による上, 垂硬化の影響を賞入 するにも曲線を修正することで容易である。

iii）逆対称変形のときは，l/i 怔若干変化しても撓角 係数の変化が少ない。

iv）同し荷重を支えるために軟鋼の代りに高張力鋼を 用いるとき，降伏点が高いからといって，細長比が 大きくなるように断面形を縮小すると塑性域での性 状が悪くなるので，縮小には注意が必要である。 などで，弾塑性におけるラーメンの柱の設計では $\mu=$ 0.02 程度に収めるのが適当ではないかという私案は安 全率の上り方など問題が多く，备方面から充分検討して 頂きたい点で，多数のご批判が得られれば幸である。

\section{[参考文献]}

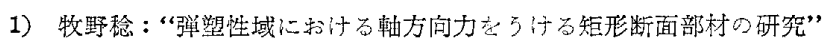
日本建築学会論文報告集 第 93 号 昭和 38 年 12 月

2) American Institute of Steel Construction "Specification for the Design, Fabrication \& Erection of Structural Steel for Buildings" 1961 